\title{
Sınıf Öğretmenlerinin Özel Yetenekli Öğrenciler İçin Etkinlik Tasarlamada-Uygulamada Karşılaştıkları Güçlükler ve Eğitime İlişkin Görüşleri*
}

\section{Difficulties That Classroom Teachers Encounter While Preparing and Applying Activities for Gifted Students And Their Opinions On The Education}

\author{
Sibel Cengizhan ${ }^{a * *}$ \\ ${ }^{a}$ Doç. Dr., Marmara Üniversitesi, Atatürk Eğitim Fakültesi, Eğitim Bilimleri Bölümü, İstanbul/Türkiye. \\ ORCID: 0000-0001-5862-2927
}

\section{MAKALE BİLGİSi}

Makale Geçmişi:

Başvuru tarihi: 01 Ocak 2019

Düzeltme tarihi: 03 Şubat 2019

Kabul tarihi: 12 Şubat 2019

Anahtar Kelimeler:

Özel Yetenekli Öğrenciler

Sınıf Öğretmeni

Etkinlik tasarlama ve uygulama
ÖZ

Araştırmanın amacı; destek eğitim odalarında görev alan sınıf öğretmenlerinin özel yetenekli ögrenciler için etkinlik tasarlamada ve uygulamada karşılaştıkları güçlüklerin ve eğitim sonrası görüşlerinin belirlenmesidir. Çalışmada nitel ve nicel verilerin bir arada toplandığı, analiz edildiği ve yorumlandığı betimsel araştırma modeli kullanılmıştır. Araştırmanın çalışma grubunu 34 sınıf öğretmeni oluşturmuştur. Anketten elde edilen bulgularda, etkinliklerin destek eğitim odalarında uygulanmasında ilk sırada süre yetersizliği gelmektedir. Araştırmaya katılan öğretmenlerin etkinlik hazırlamada karşılaştıkları güçlüklere ilişkin bulgular incelendiğinde ise; öğrencilerin yansıtıcı ve eleştirel düşünme becerilerini geliştirecek etkinlikler bulmada güçlükler yaşandığ1 saptanmıştır.

\section{A R T I C LE IN F O}

\section{Article history:}

Received 01 January 2019

Received in revised form 03 February 2019

Accepted 12 February 2019

\section{Keywords:}

Gifted Students

Clasroom Teacher

Designing and implementing activity

\begin{abstract}
A B S T R A C T
The aim of the study is to carry out the difficulties that classroom teachers took part in resource rooms, encounter while preparing and applying activities for gifted students and their opinions on the education. Descriptive research method was used to conduct the study. 34 classroom teachers held place in the work group of the study. Results of the questionnaire showed that the most significant difficulties encountered while applying the activities in the resource rooms were insufficient time. When the findings about the difficulties encountered by the teachers it was found that; In the preparation of activities appropriate it was found that there were difficulties in finding activities that would improve students' reflective and creative thinking skills.
\end{abstract}

\section{Giriş}

Bir ülkede insan kaynağının nitelikli olması, diğer kaynakların da verimli olmasına aracı olmakta ve bu da bir ülkenin gelişmişlik düzeyine olumlu yönde katkı sağlamaktadır. Bu açıdan bakıldığında eğitim-öğretim sürecindeki, özellikle doğuştan birtakım yetilerle gelen özel yetenekli öğrencilerin gelişiminin önemli olduğu göz ard1 edilemez bir gerçektir. Milli Eğitim Bakanlığı Bilim ve Sanat Merkezleri Yönetmeliği’nde özel yetenekli birey "zekâ, yaratıcılık, sanat, liderlik kapasitesi veya özel akademik alanlarda yaşıtlarına göre yüksek düzeyde performans gösteren öğrenci” şeklinde ifade edilmektedir (MEB, 2007). Subotnik, Olszewski-Kubilius ve Worrell (2011) ise özel yetenekli bireyleri, yüksek IQ ve duygusal kırılganlığa sahip, yaratıcı-üretken ve çeşitli alanlarda zekâ gelişimi sağlamış

\footnotetext{
*11-12 Mayıs 2018 tarihlerinde “I. Uluslararası Eğitimde Yeni Arayışlar Sempozyumu”nda sunulan “Özel Yetenekli Öğrenciler İçin Etkinlik Hazırlamada ve Uygulamada Öğretmenlerin Karşılaştıkları Güçlükler ve Öneriler” isimli özet bildiriden üretilmiştir.

** Sorumlu yazar/Corresponding author

e-posta: sibel@marmara.edu.tr
} 
bireyler olarak tanımlamaktadır. Benzer şekilde Renzulli (2012) de yapmış olduğu araştırmalar sonucunda özel yeteneklilik kavramını; ortalama üstü yetenek, göreve adanmışlık, yaratıcılık olmak üzere üç halkada tanımlamış ve bu halkalarda da özel yeteneklilerin entelektüel yüksek performans kapasitesine, yaratıcılığa, artistik (müzik, resim vb.) alanlarda başarıya, sıra dışı bir liderlik kapasitesine ve özel akademik alanlarda mükemmeliyetçiliğe sahip olduğunu belirtmiştir (2004). Özel yeteneklilere ilişkin tüm bu betimlemelerdeki ortak nokta; yaratıcı, orta üstü yetenekli ve adanmış yani motivasyonlarının yüksek olduğudur. Özel yetenekli bireylerin sahip olduğu bu temel özellikler dışında eleştirel düşünme, olağandan ileri analiz, sentez ve değerlendirme yapabilme becerisi gibi niteliklere de sahip olduğu bilinmektedir (Baykoç Dönmez, 2014). Bu nedenle bu bireylerin olduğundan farklı bir eğitim programına tabi tutulmaları, bunun gerçekleştirilemediği durumlarda da ülke ve toplum için kayıp olabileceği unutulmamalıdır.

Ülkemizde, özel yetenekli öğrenciler için katkı sağlayan Bilim Sanat Merkezlerinde (BİLSEM) bireysel eğitim programları kullanılmakta ancak hâlihazırda birçok problemlerle de karşılaşılmaktadır. Bu konuyla ilgili henüz bir yönetmeliğin bulunmaması ve merkezlerde örgün eğitimdeki gibi bir programın olmaması, BİLSEM'lerde uygulanan ve sadece bir yönerge kapsamında yer verilen özel yetenekliler eğitim programına yönelik önemli problemlerden biri olarak karşımıza çıkmaktadır (Kazu ve Şenol, 2012: 16). Bir diğer problem de Sak'ın (2011: 215) belirttiği gibi Türkiye'deki özel yeteneklilerin eğitiminin yalnızca birkaç program türüyle sınırlı uygulamalarının olduğudur.

Bilindiği gibi, Bilim Sanat Merkezlerinde özel yetenekli öğrencilere uygulanacak eğitim programlarında bireysel eğitim modeline bağlı kalınarak yürütülen proje tabanlı öğretim modeline göre eğitim verilmesi ve belirli aşamalardan sonra proje üretilmesi öğretmenler tarafindan hazırlanan etkinliklerle gerçekleştirilmektedir (Ülger, Uçar ve Özgür, 2014: 1100). Hazırlanacak etkinliklerin, öğrenme sürecinde öğrencilerin aktif katılımını ve bilginin transferini sağlayacak şekilde olmasının öğrencilerin; takım çalışması, iletişim, liderlik, proje yönetimi, araştırma, problem çözme, yansitma, yaşam boyu öğrenme, eleştirel düşünme becerilerinin gelişimini ve motivasyonu sağlamaktadır (Khan ve diğerleri, 2012). Bu bağlamda da öğretmenler etkinlikler düzenleyerek öğrencilerin önceki öğrenmeleri ile çelişen durumları belirleyip düşüncelerini geliştirebilmelerine öncülük edecek ve geliştirecek yaşantıları sunabilmektedirler (Küpçü, 2012: 177). Bunun için de özel yetenekli birelerin ilkokuldan itibaren özellikle sosyal ve duygusal gelişimlerinde önemli bir rol oynayan sınıf öğretmenleri tarafından düşüncelerinin, bakış açılarının ve girişimlerinin desteklendiği bir sınıf ortamında yetiştirilmeleri, öğrenme yaşantılarının akademik anlamdan çok bilişsel, duyuşsal ve psikomotor özellikler doğrultusunda birey merkezli, esnek, bilginin yeniden yapılandırılmasını sağlayıcı, özgünlüğü ve girişimciliği destekleyici bir yapıda olması önemlidir. Bu önemle ilgili olarak Fraser-Seeto'nun da (2013) belirttiği gibi özellikle sınıf öğretmenleri, öğretmen eğitimi içinde özel yetenekli öğrencileri tanımada, gerekli bilgi ve beceriyi kazanmada desteklenmelidir. Briley (1990) tarafından yapılmış deneysel bir çalışmada da özel yetenekli öğrencilere eğitim almış sınıf öğretmenlerin verdikleri eğitimin almayan öğretmenlerin verdiği eğitime göre başarıyı ve motivasyonu arttırdığı bulgusuna ulaşılmıştır. Aynı zamanda birçok araştırmada özel yetenekli öğrencilerin akademik başarılarının arttırılması ve gelişimlerinin sağlanmasında öğretmenlerin önemli bir rolü olduğu vurgulanmaktadır (Lassig, 2009; McCoach, 2007; Plunkett ve Kronborg, 2011). Bu rol içerisinde öğretmenlerin öğrenciyi tanıma, mesleki gelişim, rehberlik yapma vb. yeterliklerinin yanı sıra öğretim etkinliklerini öğrenci özellikleri doğrultusunda planlaması, hazırlaması, uygulaması, değerlendirmesi, kısacası etkinlik planı yapma konusunda da yeterliliğe sahip olması beklenmektedir. Bir etkinlik planında da ders planında olduğu gibi etkinliğin ana hatlarını vurgulayan biçimsel bölümün, dersin işlenişini vurgulayan öğrenme-öğretme süreci bölümünün ve ölçme-değerlendirme bölümlerinin olması gerekmektedir (Tanrıseven, 2016: 65). Bu bölümlerin içerisinde de kazanımların, zamanın, materyal ve kaynakların, yöntem/tekniklerin, stratejilerin ve öğrenme ortamının doğru ve verimli bir şekilde planlaması yapilmalıdır.

Bir öğretmenin etkinlik planı yapabilmesi için öncelikle etkinlik planına ilişkin hedef ve kazanımların nasıl yazılması gerektiğini, bu kazanımların hangi öğretim ilkesi, stratejisi, yöntemi ve tekniği kullanılarak gerçekleştirilebileceğini, sürecin ve sonucun nasıl değerlendirilebileceğini, uygulama, analiz, sentez ve değerlendirme basamaklarına uygun nasıl soru hazırlanacağını, kısaca öğrenci özellikleri doğrultusunda etkinlik tasarlama ve uygulamayı bilmesi önemlidir. $\mathrm{Bu}$ nedenle özellikle bireysel etkinlik planı yapmak durumunda olan öğretmenlerin bu konudaki eksiklikleri giderilmelidir. Konuyla ilgili olarak yapılmış araştırmalarda da öğretmenlerin en fazla özel yetenekli öğrencilere yönelik etkinlik hazırlamada hizmet içi eğitime ihtiyaç duydukları, verilen hizmet içi eğitimlerin yetersiz kaldığı, bireyselleştirilmiş eğitim programlarını nasıl hazırlayacaklarını bilmedikleri, farklılaştırılmış öğretim tasarımı hazırlayabilme yeterliliklerini destekleyecek şekilde bir eğitimin verilmesini bekledikleri, var olan öğretim etkinliklerinin çeşitlendirilmesi ve sayılarının artırılmasını istedikleri ve özel yetenekli öğrencilere yönelik farkındalıklarının yeterli olmadığını belirttikleri saptanmıştır (Bedur, Bilgiç ve Taşlıdere, 2015; Den-Mo ve Yew-Sheng, 1997; Hon Ming, 2010; Nar, 2017; Serin ve Korkmaz, 2014; Sürmeli, 2015). Easton, Gaffney, Janet ve Wardman (2016) yapmış oldukları çalışmada da ilkokullarda özel yetenekli bireylerin öğretimi ile ilgili sürekli mesleki gelişime duyulan ihtiyacı ve önemi belirtmişlerdir. $\mathrm{Bu}$ nedenlerle öğretmenlerin özellikle bireye göre farklılaştırılmış öğretim etkinliklerini planlayabilmesi, etkin ve doğru bir şekilde uygulayabilmesi, değerlendirmesi ve sürdürülebilir hale getirmesi önemlidir. Bunun için etkinlik planları hazırlanırken karşılaşılan eksikliklerin ve güçlüklerin belirlenerek tamamlanması, önlemler alınması ve düzenlenecek etkinlik hazırlama eğitimlerine buna göre yön verilmesi gereklidir. Bu araştırmada da bu gereklilikten yola çıkılarak özel yetenekli öğrenciler için etkinlik temelli öğretim tasarlamada ve uygulamada öğretmenlerin karşılaştıkları güçlükler belirlenmeye ve etkinlik hazırlama eğitimi sonrası görüşleri saptanmaya çalışılmıştır.

\subsection{Araştırmanın Amacı}


Araştırmanın temel amacı; destek eğitim odalarında görev alan sınıf öğretmenlerinin özel yetenekli öğrenciler için etkinlik tasarlamada ve uygulamada karşılaştıkları güçlüklerin ve eğitim sonrası görüşlerinin belirlenmesidir. $\mathrm{Bu}$ temel amaç doğrultusunda araștırmanın alt amaçları aşağıdaki gibi saptanmıştır:

1. Destek eğitim odalarında görev alan sınıf öğretmenlerinin, özel yetenekli öğrenciler için etkinlik tasarlamada karşılaştıkları güçlüklerin belirlenmesi.

2. Destek eğitim odalarında görev alan sınıf öğretmenlerinin, özel yetenekli öğrenciler için etkinlik uygulamalarında karşılaştıkları problemlerin belirlenmesi.

3. Destek eğitim odalarında görev alan sınıf öğretmenlerinin almış oldukları etkinlik eğitimi hakkındaki görüşlerinin belirlenmesi.

\section{Yöntem}

Araştırmanın bu bölümünde; araştırma modeli, katılımcılar, verilerin toplanması ve verilerin analizi başlıklarına yer verilmiştir.

\subsection{Araştırma Modeli}

Çalışma, nitel ve nicel verilerin bir arada toplandığı, analiz edildiği ve yorumlandığı betimsel bir araştırmadır. Nicel araştırma; bir grubun belirli özelliklerini belirlemek için anket, deney ve test gibi sayısal ağırlıklı verilerin toplanmasını amaçlayan tarama çalışmalardır (Baydar, Gül ve Akçil, 2007; Büyüköztürk ve diğerleri, 2018). Nitel araştırmalar ise gözlem ve görüşme gibi nitel veri toplama yöntemlerinin kullanıldığı, algıların ve olayların doğal ortamda, gerçekçi ve bütüncül bir biçimde ortaya konmasını sağlayan yaklaşımlardır (Yıldırım ve Şimşek, 2005). Bu bağlamda araştırmanın nicel boyutunu sınıf öğretmenlerinin özel yetenekli öğrenciler için etkinlik tasarlarken ve uygularken karşılaştıkları güçlüklerin belirlenmesine yönelik uygulanan anket verileri, nitel boyutunu ise sınıf öğretmenlerinin almış oldukları etkinlik hazırlama eğitimi sonundaki görüşlerini belirlemeye yönelik yarı yapılandırılmış görüşme formundan elde edilen veriler oluşturmaktadir.

\section{2. Çalıșma Grubu}

Araştırmanın evrenini İstanbul ili Ümraniye ilçesinde yer alan ve destek eğitimi odası bulunan ilkokullarda görev yapan sınıf öğretmenleri oluşturmaktadır. Ümraniye ilçesinde 38 ilkokul bulunmaktadır. Araştırmanın çalışma grubu 2016-17 eğitim-öğretim yılında 28 ilkokulda görev yapan, İstanbul Kalkınma Ajansı tarafından desteklenmiş "Pusula: Etkin Program Yetkin Öğretmen Projesi" kapsamında özel yetenekli öğrencilere etkinlik hazırlama eğitimi alan, etkinlik hazırlayan ve destek eğitim odalarında uygulayan 34 sınıf öğretmeni oluşturmuştur. Öğretmenler, öncelikli olarak hedef ve kazanım yazma, öğretim ilkeleri, stratejileri, yöntem ve teknikleri konularında teorik olarak bilgilendirilmiştir. Daha sonra ise problem çözme, eleştirel düşünme, empati, duygusal zeka, çoklu zeka, yaratıcı düşünme, yansitıcı düşünme ve çatışma çözme becerileri ile ilgili, iki ay süren 96 saatlik hem teorik hem de uygulamalı etkinlik hazırlama eğitimi almıştır.
Araștırmaya katılan öğretmenlerin \%26.5'i erkek, \%73.5'i ise kadındır. Yaş dağılımları incelendiğinde; \%14.7'sinin 25-30, \%20.6'sinın 31-36, \%41.2'sinin 37-42, \%23.5'inin ise 43 yaş ve üzeri olduğu, kıdem dağılımları incelendiğinde ise; \%26.5'inin 3-10 y1l arası, \%44.1'inin 11-18 y1l arası, \%29.4'ünün de 19 yıl ve üzeri kıdeme sahip olduğu belirlenmiştir. Bu bulgulardan, çalışma grubunun daha çok kadın öğretmenlerden oluştuğu, katılımcıların 37-42 yaş aralığında yoğunlaştığı ve kıdem olarak da 11-18 yıl arasında oldukları saptanmıştır.

Ayrıca araştırmaya katılan öğretmenlerin \%55.8'i meslekleri süresince daha önce etkinlik hazırlama ile ilgili eğitim almış, \%44.2'si ise almamıştır. Lisans eğitimleri boyunca etkinlik hazırlamaya katkı sağlayacak bir ders alan öğretmenlerin yüzdesi 52.8 iken almayanların yüzdesi 47.2'dir. Lisans eğitimleri boyunca etkinlik hazırlamaya katkı sağlayacak bir ders alan öğretmenlerin \%26.5'i drama, \%17.6's1 oyun ve fiziki etkinlikler, \%2.9'u ise drama ile öğretim materyali hazırlama ve düşünme becerileriyle ilgili ders aldıklarını belirtmişlerdir. Buna karşılık lisans eğitimleri boyunca özel yetenekli öğrencilerle ilgili herhangi bir ders almadığını belirtenlerin yüzdesi 97.1 iken alanların yüzdesi 2.9'dur.

\subsection{Verilerin Toplanmas 1}

Nicel verilerin toplanmasında anket kullanılmıştır. Anket oluşturulurken öncelikle konuyla ilgili literatür ve yapılmış araştırmalar incelenmiştir. Daha sonra etkinlik hazırlama eğitimi almış olan 20 kişilik bir öğretmen grubuna etkinlik hazırlama eğitimi almadan önce ne gibi güçlüklerle karşılaştıklarına ilişkin açık uçlu soru sorulmuş ve elde edilen cevaplar doğrultusunda anket ifadeleri hazırlanmıştır. Hazırlanan 50 maddelik anket ifadelerinin dil kontrolü Türkçe öğretmenliğinden bir öğretim üyesi tarafından yapılmış ve imla kuralları açısından düzeltilmiştir. Aynı zamanda anket, ölçme değerlendirme uzmanı ve çalışma alanı özel yetenekli öğrenciler olan iki öğretim üyesi tarafından incelenmiş ve kapsam geçerliği sağlanmıştır. Son şeklini alan 50 ifadelik anket daha önce etkinlik hazırlamış ve uygulamış olan 20 kişilik bir pilot öğretmen grubuna uygulanmış, elde edilen geri bildirimler sonucunda üç ifade birleştirilmiş (kinestetik zekâ alanında etkinlik bulamadım, etkinliklerle teknolojiyi birleştiremedim ve özgün fikirler bulmada zorluk yaşadım ifadeleri.), üç soru ise amaca hizmet etmediği için (verilen eğitimin yetersizliğinden dolayı zorluk yaşadım, okul ile ilgili görevlerimi yerine getirmede zorluk yaşadım ve öğrencilerime odaklanmada zorluk yaşadım ifadeleri) anketten çıkarılmış ve uzmanlar tarafından tekrar kontrol edilerek 44 soruya indirilmiştir. 44 soruluk anket iki bölümden oluşmaktadır. İlk bölümde araştırmaya katılan öğretmenlere ait kişisel bilgilere (yaş, cinsiyet, kıdem), ikinci bölümde etkinlik uygulamada karşılaşılan problemlere ve özel yetenekli öğrencilere ilişkin eğitim alınıp alınmadığına ilişkin üç soru sorulmuştur. Son bölümde ise öğretmen adaylarının etkinlik hazırlamada karşılaştıkları güçlüklerin belirlenebilmesi için 44 ifadeden oluşan maddeler yer almıştır. Anket maddelerine ilişkin verilen cevaplar " 1 =hiçbir zaman, 2 =bazen, 3 =her zaman" şeklinde derecelendirilmiştir. Hazırlanan ölçme aracı etkinlik hazırlama eğitiminin sonunda 34 sınıf öğretmenine uygulanmıştır. Nitel verilerin toplanmasında ise eğitim sonunda öğretmenlerle yarı yapılandırılmış görüşme 
gerçekleştirilmiştir. Yarı yapılandırılmış görüşme formunda etkinlik hazırlama eğitiminin katkıları, olumlu ve olumsuz yönlerine ilişkin sorular sorulmuştur.

\subsection{Verilerin Analizi}

Anketten elde edilen nicel veriler, SPSS istatistik paket programı ile analiz edilmiş, araştırmaya katılan öğretmenlerin ankete verdikleri cevaplara ait frekans ve yüzde değerlerine ilişkin tablolar oluşturularak bulgular kısmında sunulmuştur.

Yarı yapılandırılmış görüşme formundan elde edilen nitel verilere ilişkin olarak da; birbirine benzeyen verilerin belirli kavramlar ve temalar çerçevesinde bir araya getirilerek, okuyucunun anlayabileceği bir biçimde düzenlenip yorumlanmasını sağlayan içerik analizi yapılmıştır (Yıldırım ve Şimşek, 2005: 227). İçerik analizi gerçekleştirilirken formlara birden başlayarak Ö1, Ö2, Ö3 şeklinde numara verilmiştir. Formlara verilen cevaplar incelenmiş ve iletişim kurma, bilgileri yenileme, soru ve etkinlik hazırlama, mesleki haz, farkındalık kazanma ve bakış açısı olmak üzere 6 kategori belirlenmiştir. Sonuçların geçerliğini sağlamak için, veri analizi süreci ayrıntılı bir şekilde açıklanmış, görüşme formlarından elde edilen bulgulara ilişkin doğrudan alıntılara yer verilmiş ve yorumlar alıntılardan yola çıkılarak yapılmıştır. Araştırmanın güvenirliğini sağlamak için ise toplanan veriler iki farklı uzman tarafindan birbirinden bağımsız olarak kodlanıp kategorileştirilmiş ve yeniden düzenlenmiştir. Güvenilirliğin hesaplanması için Miles ve Huberman'ın (1994) önerdiği: R(güvenirlik)= $\mathrm{Na}$ (görüş birliği)/ $\mathrm{Na}$ (görüş birliği)+Nd(görüş ayrılığı) güvenirlik formülü kullanılmış ve hesaplama sonucunda araştırmanın güvenirliği 0.74 olarak saptanmıştır. Güvenirlik hesaplarının \%70'in üzerinde çıkması, araştırma için güvenilir kabul edilmektedir (Miles ve Huberman, 1994). Bu nedenle elde edilen sonuç, araştırma için güvenilir kabul edilmiştir.

\section{Bulgular ve Yorumlar}

Araştırmanın bu bölümünde, nitel ve nicel verilere ilişkin elde edilen bulgular sunulmuş ve yorumlanmıştır.

\subsection{Araştırmanın Birinci Alt Amacına İlişkin Bulgular}

Destek eğitim odalarında görev alan sınıf öğretmenlerinin, özel yetenekli öğrenciler için etkinlik hazırlarken karşılaştıkları güçlüklerin belirlenmesi amacıyla elde edilen nicel bulgular tablo 1. de sunulmuştur:

Tablo 1. Destek Eğitim Odalarında Görev Yapan Sınıf Öğretmenlerinin Özel Yetenekli Öğrenciler İçin Etkinlik Hazırlarken Karşılaştıkları Güçlüklere İlişkin Bulgular

\begin{tabular}{|c|c|c|c|c|c|c|}
\hline & \multicolumn{2}{|c|}{$\begin{array}{l}\text { Hiç bir } \\
\text { zaman }\end{array}$} & \multicolumn{2}{|c|}{ Bazen } & \multicolumn{2}{|c|}{$\begin{array}{c}\text { Her } \\
\text { zaman }\end{array}$} \\
\hline & $\mathrm{f}$ & $\%$ & $\mathrm{f}$ & $\%$ & $\mathrm{f}$ & $\%$ \\
\hline 1. Hedef yazmada & 2 & 5.9 & 10 & 29.4 & 22 & 64.7 \\
\hline 2. Kazanim yazmada & 2 & 5.9 & 12 & 35.3 & 20 & 58.8 \\
\hline $\begin{array}{l}\text { 3. Farklı öğretim } \\
\text { yöntem/tekniği } \\
\text { bulmada }\end{array}$ & 1 & 2.9 & 16 & 47.1 & 17 & 50.0 \\
\hline $\begin{array}{l}\text { 4. Öğretim } \\
\text { teknolojilerini } \\
\text { seçmede }\end{array}$ & 2 & 5.9 & 27 & 79.4 & 5 & 14.7 \\
\hline $\begin{array}{l}\text { 5. Beceriye ilişkin } \\
\text { ilgi ilginç giriş } \\
\text { hazırlamada }\end{array}$ & 2 & 5.9 & 21 & 61.8 & 11 & 32.4 \\
\hline
\end{tabular}

6. Gelişimsel

özelliğe uygun

resim, şekil,

karikatür vb. görsel

öğeler bulmada

$\begin{array}{lllllll}\text { 7. Etkinliklere özgün } & 7 & 20.6 & 21 & 61.8 & 6 & 17.6\end{array}$

yaratıc1 isim

bulmada

8. Özel yetenekli

öğrencilere uygun

etkinlik hazırlamada

9. Bireysel etkinlik

hazırlamada

10. Grup etkinliği

hazırlamada

11. Etkinlik süresini

belirlemede

12. Bilişsel öğrenme

alanına uygun

etkinlik hazırlamada

13. Duyuşsal

öğrenme alanına

uygun etkinlik

hazırlamada

14. Psikomotor

öğrenme alanına

uygun etkinlik

hazırlamada

15. Öğretim

stratejilerini

belirlemede

16. Kazanımlara

yönelik hikâyeler

oluşturmada

17. Özgün/yaratıc1

fikirler bulmada

18. Etkinlikleri

teknoloji ile

bütünleştirmede

19. Etkinliğe ilişkin

farklı düzeylerde

soru bulmada

20. Konuya ilişkin

ilgi çekici hikâyeler

olușturmada

21. Etkinliklerle

günlük yaşamdaki

örnekler arasında

bağlantı kurmada

22. Özel yetenekli

öğrencilerin ilgi

alanlarını

belirlemede

23. Etkinliğe aktif

katılımı sağlayacak

aktiviteler bulmada

24. Öğrenci

düzeyine uygun soru

sormada

25. Öğrenciyi

araştırmaya

yönlendirecek soru

bulmada

26. Yansitic1

düşünme becerilerini

geliştirecek farklı

değerlendirme

sorusu bulmada

27. Yansitic1

düşünme becerilerini

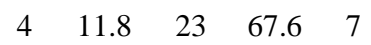

20.6

$\begin{array}{lllll}4 & 11.8 & 23 & 67.6 & 7\end{array}$

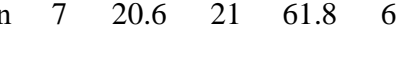

$\begin{array}{llllll}2 & 5.9 & 14 & 41.2 & 18 & 52.9\end{array}$

$\begin{array}{llllll}4 & 11.8 & 27 & 79.4 & 3 & 8.8\end{array}$

$\begin{array}{llllll}1 & 2.9 & 26 & 76.5 & 7 & 20.6\end{array}$

$\begin{array}{llllll}6 & 17.6 & 23 & 67.6 & 5 & 14.7\end{array}$

$\begin{array}{llllll}5 & 14.7 & 25 & 73.5 & 4 & 11.8\end{array}$

$\begin{array}{llllll}2 & 5.9 & 8 & 23.5 & 24 & 70.6\end{array}$

$\begin{array}{llllll}4 & 11.8 & 24 & 70.6 & 6 & 17.6\end{array}$

$\begin{array}{llllll}2 & 5.9 & 23 & 67.6 & 9 & 26.5 \\ 6 & 17.6 & 12 & 35.3 & 16 & 47.1 \\ 4 & 11.8 & 21 & 61.8 & 9 & 26.5 \\ 1 & 2.9 & 13 & 38.2 & 20 & 58.8\end{array}$

$\begin{array}{llllll}2 & 5.9 & 11 & 32.4 & 21 & 61.8\end{array}$

$\begin{array}{llllll}5 & 14.7 & 10 & 29.4 & 19 & 55.9\end{array}$

$\begin{array}{llllll}7 & 20.6 & 21 & 61.8 & 6 & 17.6\end{array}$

$\begin{array}{llllll}4 & 11.8 & 13 & 38.2 & 17 & 50.0\end{array}$


geliştirecek

durumlar/hikâyeler

olușturmada

28. Yaratic1

düşünme becerilerini

geliştirecek farklı

değerlendirme

sorusu bulmada

29. Öğrencilerin

yaratıcı düşünme

becerilerini

geliştirecek

durumlar/hikâyeler

oluşturmada

30. Çatışma çözme

$\begin{array}{lllll}7 & 20.6 & 23 & 67.6 & 4\end{array}$

11.8

becerilerinin

gelişimine yönelik

örnek olay/hikâye

oluşturmada

31. Duygusal zekâ

$\begin{array}{llllll}4 & 11.8 & 23 & 67.6 & 7 & 20.6\end{array}$

becerilerinin

gelişimine yönelik

aktivite hazırlamada

32. Problem çözme

becerilerinin

gelişimine yönelik

örnek olay/hikâye

oluşturmada

33. Eleștirel

düşünme becerilerini

geliştirecek

durumlar/hikâyeler

oluşturmada

34. Eleştirel

düşünme becerilerini

geliştirecek farklı

değerlendirme

sorusu bulmada

35. Empati kurma

becerilerinin

gelişiminini

sağlayacak

durumlar/hikâyeler

oluşturmada

36. Gelișimsel

özelliğe uygun

etkinliklerde

kullanılabilecek

video/kısa film

bulmada

37. Mantıksal-

matematiksel zekâ

alanına ilişkin

etkinlik bulmada

38. Sözel-dilsel zekâ

alanına ilişkin

etkinlik bulmada

39. Görsel-mekânsa

zekâ alanına ilişkin

etkinlik bulmada

40. İçsel-kişiye

dönük zekâ alanına

ilişkin etkinlik

bulmada

41. Sosyal-

kişilerarası zekâ

alanına ilişkin

etkinlik bulmada

$\begin{array}{lcccccc}\begin{array}{l}\text { 42. Müziksel-ritmik } \\ \text { zekâ alanına ilişkin } \\ \text { etkinlik bulmada }\end{array} & 2 & 5.9 & 24 & 70.6 & 8 & 23.5 \\ \begin{array}{l}43 . \text { Bedensel- } \\ \text { kinestetik zekâ }\end{array} & 5 & 14.7 & 22 & 64.7 & 7 & 20.6 \\ \begin{array}{l}\text { alanına ilişkin } \\ \text { etkinlik bulmada }\end{array} & & & & & & \\ \begin{array}{l}44 . \text { Doğa-varoluşçu } \\ \text { zekâ alanına ilişkin } \\ \text { etkinlik bulmada }\end{array} & 1 & 2.9 & 9 & 26.5 & 24 & 70.6 \\ \end{array}$

Tablo 1. İncelendiğinde özel yetenekli öğrenciler için etkinlik hazırlarken araştırmaya katılan sınıf öğretmenlerinin; \%64.7'sinin etkinliğe ilişkin hedef yazmada, \%58.8'inin kazanım yazmada ve etkinlikleri teknoloji ile bütünleştirmede, \%50'sinin etkinliğin gerçekleştirilmesinde kullanılabilecek farklı öğretim yöntem/tekniği bulmada, öğrencilerin eleştirel düşünme becerilerini geliştirecek durumlar/hikâyeler oluşturmada ve özel yetenekli öğrencilerin ilgi alanlarını belirlemede, \%52.9'unun özel yetenekli öğrencilere uygun etkinlik hazırlamada ve öğrencilerin yansıtıcı düşünme becerilerini geliştirecek durumlar/hikâyeler oluşturmada, \%70.6'sının duyuşsal öğrenme alanına uygun etkinlik hazırlamada ve çoklu zekâ alanlarından doğa-varoluşçu zekâ alanına ilişkin etkinlik bulmada, \%47.1'inin kazanımlara yönelik hikaye oluşturmada, \%61.8'inin etkinliğe ilişkin farklı düzeylerde soru bulmada, hedef grubun gelişimsel özelliğine uygun etkinliklerde kullanılabilecek video/kısa film bulmada ve çoklu zekâ alanlarından içsel-kişiye dönük zekâ alanına ilişkin etkinlik bulmada, \%55.9'unun konuya ilişkin ilgi çekici hikayeler oluşturmada, öğrenci düzeyine uygun soru sormada, öğrencilerin yaratıcı ve eleştirel düşünme becerilerini geliştirecek farklı değerlendirme sorusu bulmada, \%67.6'sının ise öğrencilerin yansıtıcı düşünme becerilerini geliştirecek farklı değerlendirme sorusu bulmada her zaman güçlükle karşılaştığı belirlenmiştir.

Aynı zamanda öğretmenlerin \%79.4'ünün etkinliğin gerçekleştirilmesinde kullanılabilecek öğretim teknolojilerini seçmede ve bireysel etkinlik hazırlamada, \%61.8'inin etkinlerde beceriye ilişkin ilgi çekici giriş hazırlamada, etkinliklere özgün yaratıcı isim bulmada, özgün/yaratıcı fikirler bulmada, etkinliklerle günlük yaşamdaki örnekler arasında bağlantı kurmada, öğrenciyi araştırmaya yönlendirecek soru bulmada, problem çözme becerilerinin gelişimine yönelik örnek olay/hikâye oluşturmada, empati kurma becerilerinin gelişimini sağlayacak durumlar/hikâyeler oluşturmada ve çoklu zekâ alanlarından mantıksal-matematiksel zekâ alanına ilişkin etkinlik bulmada, \%67.6'sının hedef grubun gelişimsel özelliğine uygun etkinliklerde kullanılabilecek resim, şekil, karikatür vb. görsel öğeler bulmada, etkinlik süresini belirlemede, etkinliğin gerçekleştirilmesinde kullanılabilecek öğretim stratejilerini belirlemede, etkinliğe aktif katılımı sağlayacak aktiviteler bulmada, öğrencilerin yaratıcı düşünme becerilerini geliştirecek durumlar/hikâyeler oluşturmada, çatışma çözme becerilerinin gelişimine yönelik örnek olay/hikâye oluşturmada, duygusal zekâ becerilerinin gelişimine yönelik aktivite hazırlamada, çoklu zekâ alanlarından sözel-dilsel ve görsel-mekânsal zekâ alanına ilişkin etkinlik bulmada, \%76.5'inin grup etkinliği hazırlamada, \%73.5'inin bilişsel öğrenme alanına uygun etkinlik hazırlamada, \%70.6'sının 
psikomotor öğrenme alanına uygun etkinlik hazırlamada, çoklu zekâ alanlarından müziksel-ritmik ve sosyalkişilerarası zekâ alanına ilişkin etkinlik bulmada, \%64.7'sinin ise bedensel-kinestetik zekâ alanına ilişkin etkinlik bulmada bazen güçlükler yaşadığı saptanmıştır.

\subsection{Araştırmanın İkinci Alt Amacına İlişkin Bulgular}

Destek eğitim odalarında görev alan sınıf öğretmenlerinin, özel yetenekli öğrenciler için hazırlanan etkinlikleri uygularken karşılaştıkları problemlerin, karşılaşma sıklığına göre belirlenmesi amacıyla elde edilen nicel bulgular Tablo 2.'de sunulmuştur:

Tablo 2. Destek Eğitim Odalarında Görev Yapan Sınıf Öğretmenlerinin Etkinlikleri Uygularken Karşılaştıkları Problemlere İlişkin Bulgular

\begin{tabular}{|c|c|c|c|c|c|c|}
\hline & \multicolumn{2}{|c|}{$\begin{array}{l}\text { 1. sirada } \\
\text { karş1laş1lan } \\
\text { güclükler }\end{array}$} & \multicolumn{2}{|c|}{$\begin{array}{l}\text { 2. sirada } \\
\text { karş1laş1lan } \\
\text { güclükler }\end{array}$} & \multicolumn{2}{|c|}{$\begin{array}{l}\text { 3. sirada } \\
\text { karş1laş1lan } \\
\text { güçlükler }\end{array}$} \\
\hline & $\mathrm{f}$ & $\%$ & $\mathrm{f}$ & $\%$ & $\mathrm{f}$ & $\%$ \\
\hline $\begin{array}{l}\text { 1. Süre } \\
\text { yetersizliği }\end{array}$ & 7 & 20.6 & 5 & 14.7 & 3 & 8.8 \\
\hline $\begin{array}{l}\text { 2. Etkinlik } \\
\text { konularıla } \\
\text { ilgili bilgi } \\
\text { eksikliği }\end{array}$ & 6 & 17.6 & 2 & 5.9 & 2 & 5.9 \\
\hline $\begin{array}{l}\text { 3. Araç-gereç } \\
\text { yetersizliği } \\
\text { 4. Okul }\end{array}$ & 4 & 11.8 & 10 & 29.4 & 4 & 11.8 \\
\hline $\begin{array}{l}\text { yönetimi ile } \\
\text { ilgili problemler }\end{array}$ & 1 & 2.9 & 3 & 8.8 & & \\
\hline $\begin{array}{l}\text { 5. İnternet } \\
\text { bağlantısı ile } \\
\text { ilgili problemler }\end{array}$ & 5 & 14.7 & 4 & 11.8 & 2 & 5.9 \\
\hline $\begin{array}{l}\text { 6. Aile ile ilgili } \\
\text { problemler }\end{array}$ & 1 & 2.9 & 1 & 2.9 & & \\
\hline $\begin{array}{l}\text { 7. Öğrenci } \\
\text { ilgisizliğgi }\end{array}$ & 4 & 11.8 & & & 4 & 11.8 \\
\hline 8. Fiziki & & & & & & \\
\hline $\begin{array}{l}\text { koşulların } \\
\text { yetersizliği }\end{array}$ & 5 & 14.7 & 7 & 20.6 & 8 & 23.5 \\
\hline $\begin{array}{l}\text { 9. Ekonomik } \\
\text { güçlükler }\end{array}$ & 1 & 2.9 & 1 & 2.9 & 3 & 8.8 \\
\hline $\begin{array}{l}\text { 10. Velilerle } \\
\text { ilgili güçlükler }\end{array}$ & & & 1 & 2.9 & 8 & 23.5 \\
\hline Toplam & 34 & 100.0 & 34 & 100.0 & 34 & 100.0 \\
\hline
\end{tabular}

Tablo 2. İncelendiğinde sınıf öğretmenlerinin etkinlikleri uygulamada karşılaştıkları ilk üç sıradaki güçlüklere ilişkin aşağıdaki bulgulara ulaşılmıştır:

1. Etkinliklerin uygulanmasında öğretmenlerin ilk sırada; $\% 20.6$ 'sının süre yetersizliği, \%17.6'sının etkinlik konularıyla ilgili bilgi eksikliğinin olması, \%11.8'inin araçgereç yetersizliği ve öğrenci ilgisizliği, \%2.9'unun okul yönetimi, aile ve ekonomik güçlükler, \%14.7'sinin ise internet bağlantısı ve fiziki koşulların yetersizliği ile ilgili problemlerle karşılaştığı belirlenmiştir. Elde edilen bulgulardan etkinliklerin uygulanmasında öğretmenlerin ilk sırada süre yetersizliği ile ilgili problemlerle karşılaştığı söylenebilir.

2. Etkinliklerin uygulanmasında öğretmenlerin ikinci sırada; $\% 14.7$ 'sinin süre yetersizliği, \%5.9'unun etkinlik konularıyla ilgili bilgi eksikliğinin olması, \%29.4'ünün araçgereç yetersizliği, \%8.8'inin okul yönetimi, \%11.8'inin internet bağlantıs1, \%2.9'unun aile, ekonomik ve velilerle, \%20.6'sının ise fiziki koşulların yetersizliği ile ilgili problemlerle karşılaştığı saptanmıștır. Elde edilen bulgulardan, etkinliklerin uygulanmasında öğretmenlerin ikinci sırada araç-gereç yetersizliği ile ilgili problemlerle karşılaştığı söylenebilir.

3. Etkinliklerin uygulanmasında öğretmenlerin üçüncü sırada; \%8.8'inin süre yetersizliği ve ekonomik güçlüklerle, \%5.9'unun etkinlik konularıyla ilgili bilgi eksikliğinin olması ve internet bağlantısı, \%11.8'inin araç-gereç yetersizliği ve öğrenci ilgisizliği, \%23.5'inin ise fiziki koşulların yetersizliği ve velilerle ilgili problemlerle karşılaştığ1 belirlenmiştir. Elde edilen bulgulardan etkinliklerin uygulanmasında öğretmenlerin üçüncü sırada fiziki koşulların yetersizliği ve velilerle ile ilgili problemlerle karşılaştıkları söylenebilir.

\subsection{Araştırmanın Üçüncü Alt Amacına İlişsin Bulgular}

Destek eğitim odalarında görev alan sınıf öğretmenlerinin almış oldukları etkinlik hazırlama eğitimi hakkındaki görüşlerini belirlemek amacıyla uygulanan açık uçlu yarı yapılandırılmış görüşme formundan elde edilen nitel veriler; iletişim kurma, bilgileri yenileme, soru ve etkinlik hazırlama, mesleki haz, farkındalık kazanma ve bakış açısı olmak üzere altı kategoride toplanmıştır.

\subsubsection{Iletişim Kurma Kategorisine Ait Bulgular}

Araştırmaya katılan öğretmenlerden 6'sı almış oldukları etkinlik hazırlama eğitimi sonunda özel yetenekli öğrenciler ve velilerle olan iletişimlerinin olumlu yönde geliştiğini belirtmişlerdir.

İletişim kurma kategorisiyle ilgili olarak Ö1 kodlu öğretmen görüşünü şu şekilde ifade etmiştir:

"Özel yetenekli ögrenciler ve aileleri ile daha rahat iletişim kuruyorum. Öğrencilerimin ve ailelerinin yaşadı̆̆ sorunlara çözüm bulmam kolaylaştı."

Benzer şekilde Ö11 kodlu öğretmen de "sınıf içinde bu çocuklarla daha verimli bir şekilde ilgilenilebileceğini gördüm. İletişim kurmam daha rahat oldu. İletişim için önce ben adım atıyordum ama şimdi iletişimimiz karşılıklı oldu." İfadesiyle iletişimlerinin arttığını belirtmiştir.

Ö24 kodlu öğretmen ise "eğitim sonunda sadece özel yetenekli çocuklarla değil aynı zamanda velileriyle de iletişimim arttı ve bu durum sınıftaki diğer öğrencilere de yansıdl." şeklinde görüşünü ifade etmiştir. Benzer görüşler Ö29, Ö30 ve Ö33 kodlu öğretmenler tarafindan da belirtilmiştir.

\subsubsection{Bilgileri Yenileme Kategorisine Ait Bulgular}

Bilgileri yenileme kategorisine ait elde edilen bulgularda araştırmaya katılan öğretmenlerin etkinlik hazırlama eğitimi sonunda lisans düzeyindeki derslerinde almış oldukları bilgilerini yeniden hatırladıklarını belirtmişlerdir. $\mathrm{Bu}$ kategoriyle ilgili olarak sekiz öğretmenden Ö2 kodlu öğretmen görüşünü şu şekilde belirtmiştir:

"Meslek bilgisi açısından bilgilerimi tazeleme imkânı buldum. Lisans derslerinde verilen teorik bilgileri yeniden hatırlayarak uygulamasını yapma firsatını yakaladım. Benim için çok iyi oldu. ” Benzer olarak Ö10 kodlu öğretmen de etkinlik hazırlama eğitimiyle ilgili olarak "Sahip olmadığımız ya da unuttuğumuz birçok bilgiyi hatırladık ve uygulama şansı bulamadı̆̆ımı becerileri sergiledik. Aynı 
beceri alanlarında farklı uygulamaları gördük." ifadesiyle görüşünü ifade etmiştir.

Ö5 kodlu öğretmen ise etkinlik hazırlama eğitimiyle ilgili görüşünü şu şekilde ifade etmiştir: "Her bireyin özellikle de öğretmenlik mesleğindeki bireylerin kendini geliştirmesi gerektiğini düşündügümden; birçok konuda bana katkısı olduğunu düşünüyorum. Bildiklerimi pekiştirip bilmediğim, etkinliklerimi tamamlayıp öğrendiğim bir çalışma oldu."

3.3.3. Soru ve etkinlik hazırlama kategorisine ait bulgular

Soru ve etkinlik hazırlama kategorisine ait bulgularda dokuz öğretmen, etkinlik hazırlama eğitiminin özellikle farklı düzeylerde soru ve farklı alanlarda etkinlik hazırlamaya katkı sağladığını aşağıda verilen örneklerdeki ifadelerle belirtmiștir:

"Sınıfimızdaki uygulamalarda öğrencilerimize hazırladığımız sorularımızda yeni düzenlemeler getirdik. Farklı zekâ alanlarına yönelik çalışmalar yapmamızda bize örnek oldu. Sinıfimızda da uygulanabilecek etkinlik örnekleri hazırlamaya başladık (Ö3)."

"Öğrencileri geliştirmek için ne tür etkinliklerin ve soruların faydalı olacağ l konusunda bilgi sahibi oldum (Ö20)."

"Burada yaptığımız çalışmalar sınıftaki tüm çocukların da yararına oldu. Farkll, gerçekten önemli kazanımlara yönelik soru sormanın önemini ögrendim ve sürekli uyguluyorum. Velilerim bile bunu fark eder hale geldiler. Farkl ögrenme türlerine daha fazla hitap eder hale geldim (Ö24)."

"Hem destek odası eğitiminde hem de sınıf içi uygulamalarda etkinliklerin uygulanmasında bu eğitim çok yol gösterici oldu. Özellikle soru türleri, etkinliklere göre analiz-sentez ve değerlendirme sorularl hazırlamak, etkinliği, kavramları mutlaka uygulama basamağına kadar götürmek bizi bu alanda daha etkin kllyyor (Ö34).",

\subsubsection{Mesleki Haz Kategorisine Ait Bulgular}

Mesleki haz kategorisine ilișkin elde edilen bulgularda, yedi öğretmenin etkinlik hazırlama eğitimi sayesinde güvenlerinin arttığını ve özel yetenekli bireyler için etkinlik hazırlama konusundaki kaygılarının azaldığını belirttiği saptanmiştır.

Bu bulguyla ilgili olarak Ö16 kodlu öğretmen görüşünü şu şekilde ifade etmiştir: "Gelecek dönemlerde özel yetenekli ögrrencilerle karşılaştığımda onlara etkinlik hazırlamak konusunda çok rahatım. Neler yapabilirim kaygısı taşımıyorum." Benzer şekilde Ö22 kodlu öğretmen ise etkinlik hazırlama eğitiminin "Öğrenciyi tanıma, daha iyi gözlem, bilgiyi aktarmada kolaylık ve mesleki başarı hazzl" sağladığını belirtmiştir. Ö4 kodlu öğretmen ise görüşünü "Ö̈zel yetenekli bireyler için özgün etkinlikler hazırlama konusunda başarılı olabileceğime olan inancım arttı, derste yaptığım etkinliklerin öğrencileri hangi alanda geliştirdiği konusunda farkındalık kazanmamı să̆ladı. Mesleki öz güvenimi geliştirdi. ” şeklinde belirtmişstir.

\subsubsection{Farkındalık Kazanma Kategorisine Ait Bulgular}

Farkındalık kazanma kategorisine ait bulgularda araştırmaya katılan öğretmenlerden sekizi etkinlik hazırlama eğitimi sonunda özel yetenekli öğrenciler ve karşılaştıkları problemleri daha iyi anladıklarını ve farkındalık kazandıklarını ifade etmişlerdir. Örneğin; Ö8 kodlu öğretmen “özel yetenekli bireyleri anlamak ve eğitebilmek adına farkındalık kazandım.” şeklinde görüşünü belirtirken Ö12 kodlu öğretmen de bu konudaki görüşünü şu şekilde ifade etmiştir:
"Özel yetenekli bireylere yaklaşım konusunda farkındalık kazandım. Daha önce özel yetenekli bireyler için etkinlik hazırlamanın önemi hakkında bu kadar eleştirel düşünmemiştim. Var olan etkinlikleri inceleyerek ve etkinlik hazırlayarak özel yetenekli bireylerle daha verimli bir şekilde çalışabileceğimi düşünüyorum.”

Benzer şekilde Ö15 kodlu öğretmen de "Aldiğımız etkinlik hazırlama eğitiminin özel yetenekli bireyleri tanıma, farkındalık olușturma, yönlendirme alanında bizi geliştirdiğini düşünüyorum. Farklı bilgisayar programlart aracılığıyla etkinlik hazırlamayı ögrendik. Özel yetenekli bireyleri hangi alanlarda geliştirebileceğimizi öğrendik." şeklinde görüşünü belirtmiştir. Ö18 kodlu öğretmen ise katıldığı etkinlik hazırlama eğitimine ilişkin görüşünü şu şekilde ifade etmiştir: "Akademik dilimin gelişmesi, özel yetenekli ögrencileri tanıma, derste yaptığım etkinliklerin ögrenciyi hangi alanda geliştirdiğinin daha iyi farkında oldum."

\subsubsection{Bakış Açısı Kategorisine Ait Bulgular}

Bakış açısı kategorisine ait elde edilen bulgularda beş öğretmen etkinlik hazırlama eğitiminin bakış açılarında farklılık yarattığına ilişkin görüşlerini şu şekilde belirtmiştir: "Etkinlik uygulayıcısı olarak hazırlama sürecinde işin mutfă̆ında bulunmak karşılaştığım diğer etkinlikleri de hep nasıl geliştirebilirim şeklinde eleştirel bir bakış açısı kazanmamı sağladı (Ö13).,

"Olaylara bakış açım değişti. Her gördüğ̈̈m haber veya olayı çocuklara nasıl indirgeyebilirim onlar nasıl çözüm bulabilir veya bundan nasıl gelişebilir diye düşündüm. Sinıfta ögrencilere soru sorma şeklim ve aldiğım cevaplart kullanışımdaki bakış açım değişti (Ö23)."

"Olaylara farklı bakış açısı kazandırdı. Birden fazla çözüm yolunun bulunabileceğini ve bunun ögrencilere yansitılabilecĕ̌̆ini ögrrendik (Ö21).",

"Eğitimin bireysel gelişimime etkisi oldu. Okulda, evde olaylara bakış açım daha olumlu oldu. Özellikle çatışma ve problem çözme ile empati kurma açısından (Ö14)."

\section{Sonuçlar ve Tartışma}

Destek eğitim odalarında görev alan sınıf öğretmenlerinin özel yetenekli öğrenciler için etkinlik hazırlama ve uygulamada karşılaştıkları güçlüklerin ve eğitim sonrası görüşlerinin belirlenmesi amacıyla gerçekleştirilen araştırmanın sonuçları iki temel başlık altında sunulmuştur. Birinci başlıkta araştırmadan elde edilen nicel, ikinci başlıkta ise nitel verilerden elde edilen sonuçlar ve tartışma yer almıştır.

\subsection{Nicel Verilere İlişkin Sonuçlar ve Tartışma}

Anketten elde edilen bulgularda, etkinliklerin destek eğitim odalarında uygulanmasında ilk sırada süre yetersizliği, ikinci sırada araç-gereç yetersizliği, üçüncü sırada ise fiziki koşulların yetersizliği ve velilerle ilgili güçlüklerle karşılaşıldığ (2017), Kazu ve Şenol (2012), Pemik (2017), tarafindan yapılmış araştırmalarda, öğretmenlerin destek eğitim odalarında özel yeteneklilerin eğitiminde fiziki ortam şartları, araç-gereç eksikliği, velilerin beklentileri ile ilgili sorunlarla karşılaştığı sonuçlarıyla da benzerlik göstermektedir. Aynı şekilde Çamdeviren (2014), Özer Keskin, Keskin Samancı ve Aydın (2013) tarafindan 
yapılmış araştırmalarda da bilim sanat merkezlerinde görev yapan yönetici ve öğretmenler ile özel yetenekli öğrenci aileleri fiziki koşullar, laboratuvarlardaki araç-gereçlerin ve bilgisayar sayılarının yetersizliği, öğrenci başına düşen haftalık çalışma süresinin yetersizliği ile ilgili problemlerle karşılaştıklarını ifade etmişlerdir. Tortop ve Dinçer (2016) tarafından, destek eğitim odalarında özel yetenekli öğrencilerle çalışan sınıf öğretmenlerinin uygulama hakkındaki görüşlerinin belirlenmesi amacıyla yapılmış bir çalışmada destek eğitim odalarında öğretim materyali ve öğretim ortamlarının yetersiz olduğu sonuçlarına ulaşılmıştır. Benzer olarak Kuyumcu (2011) tarafından yapılmış araştırmada da sınıf öğretmenlerinin destek eğitim odalarında öğretim materyali ve donanımı ile ilgili sıkıntılar yaşadıkları sonucuna ulaşılmıştır. Tüm bu bulgular ışığında destek eğitim odalarının fiziki koşullarının iyileştirilmesi, ders saatlerinin arttırılması, destek eğitim odalarında kullanılabilecek internet bağlantılı bilgisayar, laboratuvar araç-gereçleri vb. öğretim materyal-teknolojilerinin sağlanması ve öğrenci başına düşen haftalık çalışma sürelerinin yeniden düzenlenmesi önerilmektedir.

Araştırmaya katılan öğretmenlerin etkinlik hazırlamada karşılaştıkları güçlüklere ilişkin bulgular incelendiğinde ise sırasıyla; çoklu zekâ alanlarından doğa-varoluşçu zekâ alanına ilişkin etkinlik bulmada, duyuşsal öğrenme alanına uygun etkinlik hazırlamada, öğrencilerin yansıtıcı düşünme becerilerini geliştirecek farklı değerlendirme sorusu bulmada, etkinliğe ilişkin hedef yazmada, farklı düzeylerde soru bulmada, hedef grubun gelişimsel özelliğine uygun etkinliklerde kullanılabilecek video/kısa film bulmada, çoklu zekâ alanlarından içsel-kişiye dönük zekâ alanına ilişkin etkinlik bulmada, etkinliğe ilişkin kazanım yazmada, etkinlikleri teknoloji ile bütünleştirmede, konuya ilişkin ilgi çekici hikâyeler oluşturmada, öğrenci düzeyine uygun soru sormada, öğrencilerin eleştirel düşünme becerilerini geliştirecek farklı değerlendirme sorusu bulmada, yansıtıcı düşünme becerilerini geliştirecek durumlar/hikâyeler oluşturmada, yaratıcı düşünme becerilerini geliştirecek farklı değerlendirme sorusu bulmada, özel yetenekli öğrencilere uygun etkinlik hazırlamada, etkinliğin gerçekleştirilmesinde kullanılabilecek farklı ögretim yöntem/tekniği bulmada, özel yetenekli öğrencilerin ilgi alanlarını belirlemede, öğrencilerin eleştirel düşünme becerilerini geliştirecek durumlar/hikâyeler oluşturmada ve kazanımlara yönelik hikâyeler oluşturmada güçlükler yaşandığı saptanmıştır. Bulgular genel olarak değerlendirildiğinde araştırmaya katılan öğretmenlerin etkinlik hazırlamada daha çok farklı zekâ alanlarına, eleştirel, yansıtıcı, yaratıcı düşünmeye yönelik etkinlik ve değerlendirme sorusu hazırlamada güçlükler yaşadığı belirlenmiştir. Serin ve Korkmaz (2014) tarafindan, sınıf öğretmenlerinin hangi alanlarda hizmet içi eğitime daha fazla ihtiyaç duyduklarını belirlemek amacıyla gerçekleştirilen bir çalışmada da öğretmenlerin en fazla üstün zekâlı ya da farklı zekâ türlerine sahip öğrencilere yönelik bireysel öğrenme planları ve etkinlikler oluşturma konusunda eğitime ihtiyaç duydukları saptanmıştır. Benzer olarak Bedur, Bilgiç ve Taşlıdere (2015) tarafından yapılmış nitel bir araştırmada da öğretmenlere, destek eğitim odasında özel yetenekli öğrencilere yönelik bireyselleştirilmiş eğitim programının hazırlanmasında karşılaşılan güçlükler sorulmuş ve öğretmenler en fazla, bireyselleştirilmiş eğitim programının hazırlanmasının zor olduğunu ve nasıl hazırlayacaklarını bilmediklerini belirtmişılerdir. $\mathrm{Bu}$ öğretmenlerle yapılan görüşmeler sonucunda bir öğretmen özellikle öğrencilerin seviyesine uygun konu seçiminde ve kazanımların belirlenmesinde güçlük yaşadığını belirtmiştir. Benzer olarak Den-Mo ve Yew-Sheng (1997) tarafindan yapılan bir çalışmada da Tayvan'da özel yetenekli öğrencilerin eğitiminde öğretim etkinliklerinin var olduğu, ancak bunların çeşitlendirilmesi ve sayılarının arttırılması gerekliliği de belirtilmiştir. Tüm bunlardan yola çıkılarak öğretmen yetiştiren eğitim fakültelerindeki öğretim programlarının yenilenerek eleştirel, yansıtıcı ve yaratıcı düşünme ile ilgili dersler konulması/farklı zeka alanlarına ve konulara yönelik etkinlik hazırlama eğitimlerinin verilmesi, etkinliklerin teknoloji ile nasıl entegre edilebileceğine ilişkin bilgilerin (web 2.0 araçları) uygulamalı olarak gerçekleştirilmesi, sadece zihin engelliler öğretmenliğinde değil, diğer tüm öğretmenlik alanlarında da özel yetenekli öğrencilere ilişkin derslerin yer alması, örtük programlarının ağırlığının arttırılarak öğrencilerin daha çok duyuşsal alanlarının gelişimini sağlayacak etkinliklerin yapılması ve hedef grupların gelişimsel özelliğine uygun etkinliklerde kullanılabilecek video/kısa film gibi görsel ve işitsel materyallerin var olduğu bir etkinlik havuzunun oluşturulması önerilmektedir.

\subsection{Nitel Verilere İlişkin Sonuçlar ve Tartışma}

Öğretmenlerle etkinlik hazırlama eğitimi sonunda yapılan yarı yapılandırılmış görüşme sonunda elde edilen nitel verilerde iletişim kurma, bilgileri yenileme, soru ve etkinlik hazırlama, mesleki haz, farkındalık kazanma ve bakış açısı olmak üzere altı kategori oluşturulmuştur. Kategorilere ilişkin elde edilen sonuçlar genel olarak değerlendirildiğinde araştırmaya katılan öğretmenlerin etkinlik eğitimi sonunda; özel yetenekli öğrencilerle, bu öğrencilerin velileriyle ve diğer öğrencilerle iletişimlerinin olumlu yönde etkilendiğini, bilgilerini hatırlatma ve geliştirme konusunda yararlı olduğunu, soru ve etkinlik hazırlamaya olumlu yönde katkı sağladığını, mesleki hazzı sağladığını, özel yetenekli öğrenciler ve karşılaştıkları problemleri daha iyi anladıklarını ve farkındalık kazandıklarını, olaylara/durumlara karşı farklı bakış açısı kazandıklarını belirttikleri saptanmıştır.

Bulgular genel olarak değerlendirildiğinde öğretmenlerin aldıkları eğitimin hem mesleki hem de kişisel gelişimlerine olumlu yönde katkı sağladığını ifade edilebilir. Elde edilen sonuçlarla ilgili olarak Kazu ve Şenol (2012) tarafindan özel yetenekliler eğitim programlarına ilişkin öğretmen görüşlerinin belirlenmesi amacıyla yapılmış olan bir araştırma sonucunda da öğretmenlerin aldıkları eğitimin öğrencilerin bireysel yeteneklerinin farkında olmalarına yardımcı olduğu görüşüne daha fazla katıldıkları belirlenmiştir. Kontaş ve Yağcı (2016) tarafından yapılmış karma bir araştırma sonucunda da özel yetenekli öğrenciler için düzenlenen bir eğitim programının öğretmenlerin mesleki uygulamalarına olan yansımaları ve katkılarına ilişkin bulgularda da, katılımcılar aldıkları eğitimin üniversitede yüzeysel olarak değinilen konuların tekrar edilmesini, yeni bilgiler kazanılmasını sağladığını ifade etmişlerdir. Erişen ve diğerleri (2015) tarafından "özel yetenekli bireylerin belirlenmesi yöntem ve teknikleri kursu" programının öğretmenlerin özel yetenekli öğrencilerin özellikleri konusunda farkındalık kazanmalarına etkisini değerlendirmek üzere karma desende gerçekleştirilmiş bir 
çalışmada da eğitim sonunda öğretmenlerin özel yetenekli çocukları tanımada bilgi düzeyinin arttığı, öğrencilerine farklı bir gözle bakmayı öğrendikleri sonucuna ulaşılmıştır. Özel yetenekli öğrencilerin eğitimine yönelik gerçekleştirilen hizmet içi eğitim programının etkinliğinin araştırıldığı bir araştırmada öğretmenlerle yapılan görüşmeler sonucunda verilen eğitimin öğretmenlerin problem senaryolarının tasarımında, özel yetenekli öğrencilere rehberlik etmede ve akademik alanda özel yetenekli öğrencilerin eğitimiyle ilgili yeterlilikleri konularında katkı sağladığg sonuçlarına ulaşılmıştır (Tortop, 2014: 78).

Gross (1994) tarafından yapılmış bir araştırmada da öğretmenlerin almış oldukları hizmet içi eğitimler sonunda özel yetenekli öğrencilere ilişkin bakış açılarında olumlu yönde farklılaşma olduğunu ve farkındalık kazandıklarını belirttikleri saptanmıştır. Berman, Schultz ve Weber (2012) tarafından yapılmış bir araştırmada da özel yetenekli öğrencilere ilişkin eğitim almış öğretmenlerin almamış öğretmenlere göre özel yetenekli öğrencilere rehberlik etmede, ihtiyaçlarını saptamada daha yetkin oldukları saptanmıştır. Benzer şekilde Carly (2009) tarafından özel yetenekli öğrencilere karşı öğretmen davranışlarında mesleki gelişim ve okul kültürünün etkisinin belirlenmesi için yapılmış bir araştırma sonucunda da hizmet içi eğitim almış öğretmenlerin özel yetenekli öğrencilere karşı davranışlarının daha olumlu olduğu ve bu eğitimin mesleki gelişimlerine katkı sağladığı belirlenmiştir. Fraser-Seeto, Howard ve Woodcock (2015) tarafından yapılmış bir çalışmada da özel yetenekli öğrencilere ilişkin gerçekleştirilmiş bir eğitim sonunda öğretmenlerin özel yetenekli öğrencilere ilişkin farkındalıklarının arttığı saptanmıştır. Araştırmadan elde edilen ve belirtilen araştırma sonuçları doğrultusunda öğretmenlere özel yetenekli öğrencilere yönelik mesleki ve kişisel gelişimlerine katkı sağlayacak hizmet içi eğitimler verilmesi, bazı temel bilgi ve becerilerin tazelenmesini sağlayacak etkinliklerin düzenlenmesi, değerlendirilmesi ve sürdürülebilir hale getirilecek önlemler alınması, öğretmenler tarafindan hazırlanan etkinliklerin yer alacağı etkinlik havuzlarının oluşturulması, bundan sonraki çalışmalarda da uygulayıcılara özel yetenekli öğrencilerin karar verme, iletişim, zaman yönetimi gibi farklı alanlarda gelişimini sağlayacak etkinlikleri hazırlamaları, uygulayarak sonuçlarını değerlendirmeleri önerilmektedir.

\section{Kaynakça}

Baykoç Dönmez, N. (2011). Üstün ve özel yetenekli çocuklar ve eğitimleri. (Ed: N. Baykoç Dönmez), Özel Gereksinimli Çocuklar ve Özel Ĕ̈itim, Ankara: Eğiten Kitap.

Bedur, S., Bilgiç, N. ve Taşlıdere, E. (2015). Özel (üstün) yetenekli öğrencilere sunulan destek eğitim hizmetlerinin değerlendirilmesi. Hasan Ali Yücel Eğitim Fakültesi Dergisi, 12-1(23), 159-175.

Berman, K. M., Schultz, R.A. ve Weber, C.L. (2012). A lack of awareness and emphasis in preservice teacher training preconceived beliefs about the gifted and talented. Gifted Child Today, 35(1), 18-26.
Briley, M. F. (1990). A comparative study of student achievement, program delivery, and teacher training in $a$ gifted program, (Yayımlanmamış Yüksek Lisans Tezi). College of William and Mary School of Education, Williamsburg Virginia.

Büyüköztürk, Ş., K1lıç Çakmak, E., Akgün, Ö.E., Karadeniz, Ş. ve Demirel, F. (2018). Bilimsel Araştırma Yöntemleri (24. Bask1). Ankara: Pegem Akademi.

Carly, L. (2009). Teachers' attitudes towards the gifted: the importance of professional development and school culture. Australasian Journal of Gifted Education, 18(2), 32-42.

Çağlar, N. (2017). Illköğretim kurumlarındaki "Destek eğitim odası (DEO)" uygulamasına ilişkin okul yöneticileri ve öğretmenlerin görüşlerinin incelenmesi, (Yayımlanmamış Yüksek Lisans Tezi). Gazi Üniversitesi Eğitim Bilimleri Enstitüsü, Ankara.

Çamdeviren, Ş. (2014). Bilim ve sanat merkezine (BILSSEM) devam eden üstün yetenekli çocukların anne babalarının karşılaştıkları güçlükler (Sakarya ili örneği), (Yayımlanmamış Yüksek Lisans Tezi). Sakarya Üniversitesi Eğitim Bilimleri Enstitüsü, Sakarya.

Den-Mo, T. Ve Yew-Sheng, S. (1997). Gifted education in Taiwan: services, problems and challenges. Annual Convention of the Council for Exceptional Children, 1(22), 8-13 April, Salt Lake.

Easton, V., Gaffney, J.S. ve Wardman, J. (2016). "I need to do better, but I don't know what to do": primary teachers' rxperiences of talented young writers. Australasian Journal of Gifted Education, 25(2), 34-51.

Fraser-Seeto, K.T. (2013). Pre-service teacher training in gifted and talented education: An Australian perspective. Journal of Student Engagement: Education Matters, 3(1), 29-38.

Fraser-Seeto, K.T., Howard, S.J. ve Woodcock, S. (2015). An investigation of teachers' awareness and willingness to engage with a self-directed professional development package on gifted and talented ducation. Australian Journal of Teacher Education, 40(1), 1-14.

Gross, M. U. M. (1994). Changing teacher attitudes to gifted students through inservice training. Gifted and Talented International, 9(1), 15-21.

Hon Ming, MA. (2010). Gifted education in Hong Kong: perceptions of teachers, parents and experts, (Yayımlanmamış Yüksek Lisans Tezi). University of Technology Sydney, Faculty of Arts \& Social Sciences, Australia.

Kazu, İ. Y. ve Şenol, C. (2012). Üstün yetenekliler eğitim programına ilişkin öğretmen görüşleri (BİLSEM örneği). e-Uluslararası Eğitim Araştırmaları Dergisi, 3(2), 1335.

Khan, M., Muhammad, N., Ahmed, M., Saeed, F. ve Khan, S.A. (2012). Impact of activity-based teaching on students' academic achievements in physics at secondary level. Academic Research International, 3(1), 146-156. 
Kontaş, H. ve Yağc1, E. (2016). Bilsem öğretmenlerinin program geliştirme ihtiyaçlarına ilişkin geliştirilen programın etkililiği. Abant İzet Baysal Üniversitesi Eğitim Fakültesi Dergisi, 16(3), 902-923.

Kuyumcu, Z. (2011). Bireyselleştirilmiş eğitim planı geliştirilmesi ve uygulanmasi sürecinde ögretmenlerin yaşadıkları sorunlar ve bu sorunlara yönelik çözüm öneriler, (Yayımlanmamış Yüksek Lisans Tezi). Ankara Üniversitesi Eğitim Bilimleri Enstitüsü, Ankara.

Küpçü, A.R. (2012). Etkinlik temelli öğretim yaklaşımının ortaokul öğrencilerinin orantısal problemleri çözme başarısına etkisi. Ahi Evran Üniversitesi Kırşehir Eğitim Fakültesi Dergisi, 13(3), 175-206.

Lassig, C. (2009). Teachers' attitudes towards the gifted: The importance of professional development and school culture. Australasian Journal of Gifted Education, 18 (2), 32-42.

McCoach, D.B. (2007). What predicts a teachers' attitudes towards the gifted?. Gifted Child Quarterly, 51(3), 246255.

Miles, M. B. \& Huberman, A.M. (1994). Qualitative data analysis: an expanded sourcebook. (2nd Edition). Calif. : SAGE Publications.

Milli Eğitim Bakanlığı, (2007). Bilim ve Sanat Merkezleri Yönergesi. Erişim adresi: http://orgm.meb.gov.tr/meb_iys_dosyalar/2015_09/181 01802_bilimvesanatmerkezleriynergesi.pdf

Nar, B. (2017). Üstün / özel yetenekli ögrencilere yönelik destek eğitim odası uygulaması: Sını öğretmenlerinin öz yeterlikleri ve görüşleri, (Yayımlanmamış Yüksek Lisans Tezi). İstanbul Aydın Üniversitesi Sosyal Bilimler Enstitüsü, İstanbul.

Özer Keskin, M., Keskin Samancı, N. ve Aydın, S. (2013). Bilim ve Sanat Merkezleri: mevcut durumları, sorunları ve çözüm önerileri. Üstün Yetenekli Eğitimi Araştırmaları Dergisi, 1(2), 78-96.

Pemik, K. (2017). Özel yetenekli ögrencilere destek odasında verilen eğitime ilişkin okul yöneticilerinin ve ögretmenlerin görüşleri, (Yayımlanmamış Yüksek Lisans Tezi). Marmara Üniversitesi Eğitim Bilimleri Enstitüsü, İstanbul.
Plunkett, M. \& Kronborg, L. (2011). Learning to be a teacher of the gifted: The importance of examining opinions and misconceptions. Gifted and Talented International, 26(1), 31-46.

Renzulli, J.S. (2012). Reexamining the role of gifted education and talent development for the 21st century: a four-part theoretical approach. Gifted Child Quarterly, $56(3), 150-159$.

Renzulli, J.S. Reis, S.M. (2004). Identification of students for gifted and talented programs. California:Corwin Press.

Sak, U. (2011). Üstün yetenekliler eğitim programları modeli (ÜYEP) ve sosyal geçerliliği. Ĕgitim ve Bilim, 36 (161), 213-229.

Serin, M. K. ve Korkmaz, İ. (2014). Sınıf öğretmenlerinin hizmet içi eğitim ihtiyaçlarının analizi. Ahi Evran Üniversitesi Kırşehir Eğitim Fakültesi Dergisi, 15(1), 155-169.

Sürmeli, V. (2015). Sinıf ögretmenlerinin üstün yetenekli ögrenciler hakkındaki farkındalı düzeyleri, (Yayımlanmamış Yüksek Lisans Tezi). İstanbul Gelişim Üniversitesi Sosyal Bilimler Enstitüsü, İstanbul.

Tanrıseven, I. (2016). Öğretimde Plan. Tuğba Yanpar Yelken ve Cenk Sayın (Ed.) Ögrretim Illke ve Yöntemleri içinde (s. 43-76). Ankara: AnıYayıncılık.

Tortop, H. S. ve Dinçer, S. (2016). Destek eğitim odalarında üstün/özel yetenekli öğrencilerle çalışan sınıf öğretmenlerinin uygulama hakkındaki görüşleri. Üstün Yetenekli Eğitimi Araştırmaları Dergisi, 4(2), 11-28.

Tortop, H.S. (2014). Examining the effectiveness of the inservice training program for the education of the academically gifted students in Turkey: a case study. Journal for the Education of the Young Scientist and Giftedness, 2(2), 67-86.

Ülger, B.B., Uçar, S. ve Özgür, İ. (2014). İdareci, öğretmen ve öğrencilerin bakış açısından Bilim Sanat Merkezlerinde Uygulanan Fen Eğitimi Programı. Ilkögrretim Online, 13(3), 1098-1121.

Yıldırım, A. ve Şimşek, H. (2005). Sosyal Bilimlerde Nitel Araştırma Yöntemleri. Ankara: Seçkin Yayıncılık. 